\section{URINARY TRACT INFECTION}

\section{A COMPARATIVE STUDY IN THE DIABETIC AND} GENERAL POPULATIONS

\section{BY}

D. J. O'SULLIVAN, M.B., M.R.C.P. Senior Medical Registrar, Birmingham General Hospital

M. G. FitzGERALD, M.D., M.R.C.P. Research Fellow, Birmingham General Hospital

M. J. MEYNELL, M.D., M.R.C.P. Clinical Pathologist, Birmingham General Hospital AND

J. M. MALINS, M.D., F.R.C.P. Consultant Physician, Birmingham General Hospital

It is generally believed that diabetes mellitus predisposes to infections of the urinary tract and that these are commoner in the diabetic than in the general population. Most of the studies which confirm these opinions are based on the findings at necropsy on diabetics dying in hospital (Sharkey and Root, 1935 ; Baldwin and Root, 1940 ; Barnard et al., 1953), in whom the incidence of terminal urinary-tract infection would be expected to be high. Studies on living diabetic patients often lack direct controls or fail to take age or sex into account. The relatively few, and contradictory, reports on the prevalence of infections of the urinary tract in the general population refer to patients in hospital (Ophüls, 1926 ; Loopuyt, 1946), or attending medical out-patient departments (Kass, 1956). However, Kass (1955) and others revived the use of quantitative bacterial counts obtained by culture of freshly voided urine, thereby providing a diagnostic method by which comparison between the diabetic and general population can be made. Such a study is here described.

\section{Material and Methods}

The age in 20-year groups and sex distribution of the current attenders at a large diabetic clinic $(3,841$ patients) was determined. 150 patients, whose age and sex correspond with that of the total clinic population, were selected at random and the freshly passed midstream specimen of urine was collected and cultured quantitatively by the methods described below. The identical procedure was carried out in 150 non-diabetic controls of similar age and sex distribution. These were patients attending the casualty department with minor trauma, and their friends and relatives. Care was taken to exclude any patient attending with other than minor trauma, since it was felt that in this way the controls would be as representative as possible of the general population.

Technique of Collection and Culture of Specimens.In males the glans penis was swabbed with $1 / 1,000$ benzalkonium chloride ("roccal") and a mid-stream specimen of urine collected. Female patients were prepared in the dorsal lithotomy position, as for catheterization, with the same antiseptic. The labia were separated, the patient was encouraged to void urine, and a specimen from the mid-portion of the urinary stream was collected into a sterile container. Specimens were dealt with immediately after collection. Serial tenfold dilutions of urine $1: 10$ to $1: 1,000.000$ were made in sterile normal saline, and $1 \mathrm{ml}$. of each dilution was mixed with $10 \mathrm{ml}$. of molten nutrient agar kept at $50^{\circ} \mathrm{C}$., then poured into a Petri dish and allowed to set.
The six plates were cultured aerobically at $37^{\circ} \mathrm{C}$. for 48 hours. The plate containing approximately 50-200 colonies was counted, and the number multiplied by the dilution gave the number of viable organisms per $\mathrm{ml}$.* Duplicates were at first put up anaerobically as well, but the total counts did not differ significantly, and this procedure was therefore discontinued.

A count of more than 100,000 organisms per ml. was considered to be indicative of infection of the urinary tract (see below). Counts below 10,000 per ml. probably represent the range of contamination, while counts of 10,000 to 100,000 per $\mathrm{ml}$. are of doubtful significance (Kass, 1956 ; Merritt and Sanford, 1958).

\section{Results}

Table I shows the age and sex composition of both diabetics and controls. The preponderance of middleaged and elderly women (determined by the large number of these in the diabetic population) is evident. Bacterial counts of more than 100,000 per ml. of urine

TABLB I.-Percentage Age and Sex Composition of 300 Subjects

\begin{tabular}{|c|c|c|c|c|c|}
\hline & Age: & $0-19$ & $20-39$ & $40-59$ & $60+$ \\
\hline $\begin{array}{l}\text { Females } \\
\text { Males }\end{array}$ & $\begin{array}{ll}. . & \end{array}$ & 2 & $\begin{array}{l}6 \\
7\end{array}$ & $\begin{array}{l}17 \\
16\end{array}$ & $\begin{array}{l}36 \\
14\end{array}$ \\
\hline
\end{tabular}

were obtained in $20(13.3 \%)$ of the diabetics and in 18 $(12.0 \%)$ of the controls. Thus there was no significant difference in the incidence of infection of the urinary tract between the two groups.

Table II shows the results of the bacterial counts for the 300 subjects and the striking similarity between diabetics and controls at every level of bacterial count can be seen.

Sex.-In Table II the sex incidence of the varying degrees of bacteriuria is also seen. The excess of females among those with infection of the urinary tract is striking: of the 20 infected diabetics 18 were women, while, of the controls, only one of the 18 subjects with infection of the urinary tract was male.

TABLE II.-Bacterial Counts in 300 Subjects

\begin{tabular}{|c|c|c|c|c|}
\hline \multicolumn{2}{|c|}{ Organisms $/ \mathrm{ml}$. Urine } & Females & Males & Total \\
\hline More than 100 , & & $\begin{array}{l}18 \\
17\end{array}$ & $\begin{array}{l}2 \\
1\end{array}$ & $\begin{array}{l}20 \\
18\end{array}$ \\
\hline $10,000-100,000$ & $\because$ & $\begin{array}{l}11 \\
15\end{array}$ & $\begin{array}{l}6 \\
2\end{array}$ & $\begin{array}{l}17 \\
17\end{array}$ \\
\hline $1,000-10,000$ & $\begin{array}{l}\ldots \\
\ldots\end{array}$ & $\begin{array}{l}24 \\
24\end{array}$ & $\begin{array}{r}9 \\
10\end{array}$ & $\begin{array}{l}33 \\
34\end{array}$ \\
\hline $0-1,000$ & $\begin{array}{l}\text {. } \\
\text {. }\end{array}$ & $\begin{array}{l}19 \\
24\end{array}$ & $\begin{array}{l}29 \\
33\end{array}$ & $\begin{array}{l}48 \\
57\end{array}$ \\
\hline No count & $\ddot{n}$ & $\begin{array}{l}19 \\
11\end{array}$ & $\begin{array}{l}13 \\
13\end{array}$ & $\begin{array}{l}32 \\
24\end{array}$ \\
\hline
\end{tabular}

Age.-The Chart shows the numbers infected in each 20-year age-group of both diabetics and controls, expressed as a percentage of the total numbers examined. In Table III the actual numbers of patients with infection of the urinary tract in the different agegroups are shown. In subjects up to the age of 40 we found only one infected-urine in 25 , but after this age the incidence of infection increased markedly, and, in the women aged 60 and over, 24 of 108 examined $(22 \%)$ had bacterial counts of over 100,000 per $\mathrm{ml}$.

*As an alternative, a standard-sized loopful of freshly voided urine can be rubbed over the surface of an agar plate. With a conversion graph, the colony count obtained by this method can be correlated with the viable count as obtained above. This latter method obviates the lengthy procedure required in the dilution technique (O'Sullivan et al., 1960). 
TABLE III.-Age Distribution of the 38 Patients with Infection of the Urinary Tract

\begin{tabular}{rr|c|c|c|c}
\hline & Age : & $0-19$ & $20-39$ & $40-59$ & $60+$ \\
\hline Diabetics.. & $\cdots$ & 0 & 1 & 5 & 14 \\
Controls.. & $\cdots$ & 0 & 0 & 7 & 11 \\
\hline Totals & $\cdots$ & 0 & 1 & 12 & 25
\end{tabular}

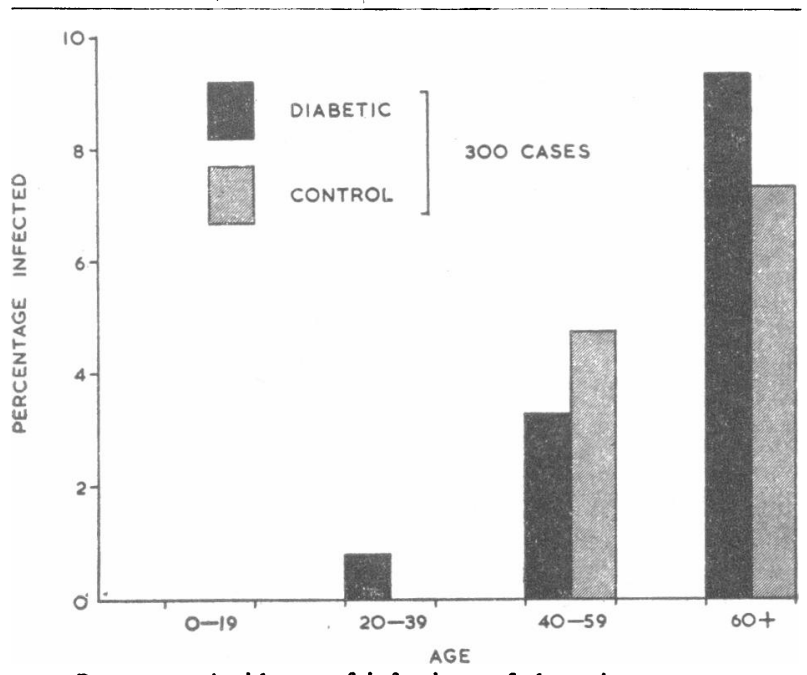

Percentage incidence of infections of the urinary tract.

Bacteriology

The identification of the bacterial species found in the urine in relation to the various colony counts is of interest and is shown in Table IV. In urines with high bacterial counts, coliform organisms were the commonest found and often in pure culture. The other

TABLE IV.-Organisms Found at Various Levels of Bacterial Counts

\begin{tabular}{|c|c|c|c|c|c|c|c|c|}
\hline & \multicolumn{2}{|c|}{$>100,000$} & \multicolumn{2}{|c|}{$\begin{array}{l}10,000 \\
\mid 100,000\end{array}$} & \multicolumn{2}{|c|}{$\begin{array}{l}1,000- \\
10,000\end{array}$} & \multicolumn{2}{|c|}{$\stackrel{0-}{1,000}$} \\
\hline & D & C & D & C & D & C & D & C \\
\hline \multirow[t]{2}{*}{$\begin{array}{l}\text { E. coli } \\
\text { P. vulgaris } \\
\text { B. lactis aerogenes } \\
\text { Str. faecalis } \\
\text { Staph. albus and } \\
\text { diphtheroids }\end{array}$} & $\begin{array}{r}11 \\
2 \\
1 \\
1\end{array}$ & $\begin{array}{l}6 \\
2 \\
1 \\
4\end{array}$ & $\begin{array}{l}\mathbf{1} \\
\mathbf{1} \\
\mathbf{1} \\
\mathbf{5}\end{array}$ & $\begin{array}{l}3 \\
2 \\
1 \\
2\end{array}$ & $\begin{array}{r}1 \\
0 \\
2 \\
10\end{array}$ & $\begin{array}{l}3 \\
2 \\
0 \\
3\end{array}$ & $\begin{array}{l}4 \\
2 \\
1 \\
3\end{array}$ & $\begin{array}{l}3 \\
2 \\
2 \\
3\end{array}$ \\
\hline & 5 & 5 & 9 & 9 & 20 & 26 & 37 & 47 \\
\hline
\end{tabular}

common pathogens of the urinary tract, Proteus vulgaris and Bacillus lactis aerogenes, were also relatively frequent at higher counts. In the low count specimens Staph. albus and diphtheroids-the common contaminants-were the usual bacteria isolated in colony cultures, while Escherichia coli and P. vulgaris were relatively infrequent. These findings, also noted by others (Kass, 1955, 1956; Huvos and Rocha, 1959), increase the significance of high bacterial counts. It can be seen, too, that there was no significant difference in the bacterial flora of the diabetics and the controls.

The one respect in which the diabetic patients differed from the controls was the height of the bacterial counts among those infected. Of the 20 diabetics considered to have infection of the urinary tract because of counts of more than 100,000 organisms per ml., 15 had counts of more than $1,000,000$ per ml., while only 7 of the 18 infected controls had counts in this latter range. If the number of bacteria grown is an index of the severity of the infection, then, while the incidence of infection is the same in both groups, the diabetics seem to be more severely affected. A more probable explanation is that the infected diabetic patients had heavy glycosuria at the time the specimen was collected and the presence of glucose rendered the urine a more favourable medium for the multiplication of organisms. The influence of glycosuria on bacterial counts was investigated further, and it was found that the addition of $2 \%$ of glucose to normal urine inoculated with $E$. coli in vitro caused a fourfold increase in the bacterial count after two hours at $37^{\circ} \mathrm{C}$.

\section{Discussion}

The wide discrepancy between the frequency of pyelonephritis in necropsy material, where it has been found in from 6 to $20 \%$ of cases, and its prevalence in living patients led several observers to seek methods of assessing infection of the urinary tract other than the traditional one of microscopy and qualitative culture of the catheter specimen of urine in the female and the mid-stream specimen in the male. The growing evidence implicating catheterization (Guze and Beeson, 1956; Beeson, 1958) as a factor in the pathogenesis of infection of the urinary tract has stressed further the desirability of a reliable method of evaluating non-catheter urine specimens. The revival of quantitative bacterial counts by serial dilution of urine specimens led to a new interest in this subject and to a number of publications concerning the prevalence of asymptomatic infections of the urinary tract in various groups of hospital populations.

The findings to date indicate that contamination and true bacteriuria may be distinguished by counting the numbers of bacteria in the urine (Kass, 1955). This has been confirmed by correlations between bladder urine aspirated through the abdominal wall and cleancatch mid-stream specimens (Monzon et al., 1958) and between catheter specimens and clean-catch specimens (Boshell and Sanford. 1958 : Merritt and Sanford. 1958). MacDonald et al. (1957), collecting bladder urine after death and correlating the colony counts with the pathological findings at necropsy, conclude that bacterial counts are a reliable means of detecting true bacteriuria and that such bacteriuria is often associated with active infection of the kidneys and other structures of the urinary tract. There is some difference of opinion about the initial level of bacterial count above which infection of the urinary tract is considered to be present, figures of from 10.000 to 100,000 being quoted by various workers (Kass, 1956; Huvos and Rocha, 1959), but all are agreed that counts above 100,000 per $\mathrm{ml}$. are significant; therefore our results certainly do not overestimate the incidence of infection.

The main finding of the present investigation-that infection of the urinary tract is no more common among diabetics than among non-diabetic controls from the general population-is in disagreement with current opinions, which may be summed up by Beeson's (1955) statement, "urinary tract infection is commoner in diabetics than in non-diabetics, although precise data on this is lacking." It is claimed on hypothetical grounds that metabolic disturbances in diabetes influence directly mechanisms of resistance to infection. Yet in experimentally produced diabetes no significant alteration in resistance to administered pathogens has been observed (Perla and Marmorston, 1941: Schofield and Baker, 1956), while at necropsy Robbins and Tucker (1944) found that the incidence of infections other than renal ones was about the same in diabetic as in non-diabetic patients. Clinical impressions have always suggested an increased incidence of infection of the urinary tract 
among diabetics, but since both diabetes and infections of the urinary tract occur most commonly in middleaged and elderly women, it is not surprising that the number of diabetics with infections should seem large. The greater hazard of infections in diabetic patients serves also to make them more memorable.

Previous reports have, with one exception (Huvos and Rocha, 1959), found a higher incidence of infection in diabetics than in non-diabetics. The great majority, however, base their findings either on the results of necropsies on patients dying in hospital or on hospital in-patients. The lack of controlled studies on a diabetic out-patient population and "healthy" non-diabetics is surprising. Thus Barnard et al. (1953), in a series of 100 necropsies on diabetics dying in hospital, found that $30 \%$ had suffered significant infection of the urinary tract. Merritt and Sanford (1958) examined 100 consecutive ambulatory and non-ambulatory admissions to a medical ward and found a significant excess of patients with diabetes in the group with positive cultures. It is probably invalid to apply results from an investigation such as this, based on hospital admissions, to a general population, either diabetic or non-diabetic, particularly as Rengarts (1960), studying diabetic admissions to the Joslin Clinic Service, found a much higher incidence of urinary infections in patients confined to bed than among ambulatory diabetics. In this latter study the incidence of infection among ambulatory diabetics (14\% of 43 patients) was very similar to the present findings.

That infections of the urinary tract are commoner in women than in men has long been recognized, and a marked excess of infected females is seen in the present series, as in others (Kass, 1955, 1956 ; Rengarts, 1960). The striking significance of age in determining the incidence of infection is not so widely appreciated, but where it has been taken into account the number of patients infected has risen steadily with age in both diabetics (Huvos and Rocha, 1959) and non-diabetics (Loopuyt, 1946). Kass, in an extensive study, found that $18 \%$ of 54 female diabetics and only $6 \%$ of 337 females attending as out-patients had infections of the urinary tract, but makes no mention of the ages of either group, so that it is difficult to assess the significance of his findings. Failure to take into account the large numbers of middle-aged and elderly women in the diabetic population is probably the main reason for the present confusion of thought on this subject.

Finally, although adequate figures are available regarding the incidence of infections of the urinary tract in hospital in-patients (Marple, 1941 ; Loopuyt, 1946), there is a striking lack of information about the general population. The need to obtain catheter specimens of urine from the female for reliable bacteriological and microscopical study has in the past been an understandable deterrent. Quantitative examination of clean-catch voided specimens now provide a safe and relatively simple method of evaluating infections of the urinary tract, and its use in "healthy" populations such as the controls in the present study could with advantage be extended further. Only in this way will the significance of asymptomatic infections be recognized, their possible association with other disorders such as hypertension be elucidated, and methods for their control be put on a more effective and adequate basis.

\section{Summary}

The use of quantitative bacterial counts on clean voided urine specimens is described.
A comparison of the incidence of infections of the urinary tract in 150 randomly selected diabetics, representative of a large diabetic clinic, with a similar number of non-diabetic "healthy" controls shows no significant difference between the two groups.

The high incidence of infection of the urinary tract in middle-aged and elderly women in both groups is noted and its significance discussed.

We wish to thank Miss M. A. Butcher for technical assistance and the staff of the casualty department of the Birmingham General Hospital for their co-operation. This work was in part supported by a grant from the Diabetic Association.

REFERENCES

Baldwin, A. D., and Root, H. F. (1940). New Engl. J. Med., 223, 244 .

Barnard, D. M., Story, R. D., and Root, H. F. (1953). Ibid. 248, 136.

Beeson, P. B. (1955). Yale J. Biol. Med., 28, 81

(1958). Amer. J. Med., 24, 1.

Boshell, B. R., and Sanford, J. P. (1958). Ann. intern. Med., 48 1040 Guze, L. B., and Beeson, P. B. (1956). New Engl. J. Med., 255,

Huvos, A., and Rocha, H. (1959). Ibid., 261, 1213

Kass, E. H. (1955). Amer. J. Med., 18, 764.

- (1956). Trans. Ass. Amer. Phycns, 69, 56

Loopuyt, L. (1946). Acta med. scand., 125, 245.

Marple, C. D. (1941). Ann. intern. Med., 14, 222.

MacDonald, R. A., Levitin, H., Mallory, G. K., and Kass, E. H (1957). New Engl. J. Med., 256, 915.

Merritt, A. D., and Sanford, J. P. (1958). J. Lab. clin. Med., 52, 463 .

Monzon, O. T. Ory, E. M., Dobson, H. L., Carter, E., and Yow, E. M. (1958). New Engl. J. Med., 259, 764

Ophüls, W. (1926). Stan. Univ. Publ. med. Sci., 1, 127.

O'Sullivan, D. J., Fitzgerald, M. G., Meynell, M. J., and Malins, J. M.'(1960). J. clin. Path., 13, 527.

Perla, D., and Marmorston, J.' (1941). Natural Resistance and Clinical Medicine. Little, Brown, Boston.

Rengarts, R. T. (1960). Amer. J. med. Sci., 239, 159. 231, 865 .

Schofield, R. A., and Baker, R. D. (1956). Arch. Path. (Chicago), 61, 407.

Sharkey, T. P., and Root, H. F. (1935). J. Amer. med. Ass., 104 2231 .

\section{VARICOCELE: A TREATABLE CAUSE OF SUBFERTILITY}

BY

\section{STUART SCOTT, M.D., Ch.M., F.R.C.S.Ed. F.R.F.P.S.}

Consultant Surgeon to the Male Subfertility Clinic, Western Infirmary, Glasgow

Disappointment at the results of drug therapy in the treatment of male subfertility (Scott, 1959) has given way to increasing optimism as regards the results now being achieved by surgery. Before Tulloch (1952) first reported restoration of fertility in an azoospermic man after varicocele ligation, a varicocele was seldom if ever considered as a possible cause of subfertility. Russell (1954) later noted that the incidence of varicocele was much greater in men attending a subfertility clinic than in the husbands of women attending his antenatal clinic. Finally, I showed that subfertility could be detected in $66 \%$ of varicocele patients compared with only $39 \%$ of those with no varicocele (Scott, 1958a). Persistence of a varicocele beyond the age of 30 years resulted in progressive deterioration of fertility in the cases studied by Russell (1957), and I subsequently reported three cases of progressive subfertility over a period of five years which was finally checked and returned to acceptable fertility by varicocele ligation (Scott, 1960a). 